\title{
Relationship between legitimation, competition and organizational death: current state of the art
}

\section{Manuel Núñez Nickel and José Moyano Fuentes}

There is agreement among ecology researchers that the concepts of legitimation and competition are partly responsible for organizational selection. Finding adequate measures to represent these concepts, however, has been elusive and has been the main obstacle to the development of this stream of investigation. On the basis of the germinal density dependence model, we identify two lines of research, which have generated seven distinct models. This survey shows that there has been a general tendency to use only three variables to measure legitimation and competition, which are often measured together. However, we argue that fruitful results have emerged when efforts have been made to separate both concepts and that there is some potential in using new measures (mass or concentration) which have so far only found limited application in the field of population demography. These findings, together with the inconclusive results of this stream of research, allow us to identify the existing gaps in the literature and comment on directions for future research.

\section{Introduction}

The organizational ecology theory originally formulated by Hannan and Freeman (1977) emphasizes the role of environmental selection forces, measured by organizational mortality, in relation to the chances of adaptation of individual organizations.
One of the principal theoretical models that have been developed within this theory considers that both legitimation and competition processes are the main cause of organizational mortality (Hannan 1989). A form gains legitimation when it attains a socially taken-for-granted character (Meyer and Rowan 1977). Legitimation enhances 
the life chances of an organization as it eases the problem of maintaining flows of resources from the environment. Conversely, competition has been considered as the fight between organizations, belonging to one particular population, to obtain the limited resources necessary for survival (Hannan and Freeman 1977). Therefore, competition will exert a negative influence on the probability of organizational survival.

Within these general lines of thinking, finding measures that adequately represent the concepts of legitimation and competition has been the main problem and has provoked a stream of investigation including the different models that appear in this paper.

The density dependence model (Hannan 1989), which directly links the population density to mortality rates, is the first attempt developed to analyse this relationship.

However, density, defined as the number of organizations in one population, is a variable that presents various limitations. It does not take into account competition effects between organizations which, having identical resource necessities, form part of another/ other population(s), or, being part of the same population, may not compete, since they are geographically separated, or of a completely different magnitude. Thus, a group of models arises which introduces connotations to the density variable. There is also another group of models which introduce variables other than density.

These contributions, together with their empirical contrasts, have not only created a stream of research, which is currently in force and completely up to date (Carroll 1997), but are proving to be a source of inspiration for the development of other theoretical approaches. For this reason, we aim to assess the current state of these contributions, compiling the literature supporting it. Although there are other studies that include this stream of research (Amburgey and Rao 1996; Baum 1996; Carroll and Hannan 2000; Singh and Lumsden 1990; Van Witteloostuijn 2000), they are more general, since they focus on organizational ecology, considered as a theoretical field incorporated in the theory of organization.

It is of interest to concentrate efforts on this stream of research to obtain a deeper understanding, and hence be able to assess it more rigorously. On an operational level, the aim is to accomplish the following objectives:

(1) define and clarify the problem in question, given that existing studies cover different objectives, making it difficult to compare results

(2) compile previous research papers to facilitate the work to be done by new researchers wishing to undertake this line of study

(3) make a critical assessment, identifying relationships, contradictions and inconsistencies that arise in the literature

(4) report on the current state of this stream of research with the test and validation level of the different models that have arisen

(5) discover some of the challenges that must be faced in the near future.

To achieve these objectives, this paper is set out in the following sections: (1) a general classification of the models created up to now covering the subject in question; (2) the initial development of a density dependence model, going into its basic hypothesis, as well as the most relevant connotations that have been considered the basis of all other models; (3) the theoretical and empirical development of the models, which, without discarding the density variable, provide new questions to be studied; (4) alternative models that study the phenomenon on the basis of different variables; and, lastly, (5) we present our conclusions together with what we consider to be gaps still existing in this extensive stream of research.

\section{General Classification of Models}

The organizational ecology theory explains mortality of organizations as the result of the effect produced by the combination of two general social processes: legitimation and 
competition. Although there is complete agreement as to which are the underlying concepts of both processes, authors find it extremely difficult to measure them. There are no variables that directly cover the effects of such processes. That is why researchers have been forced to use diverse approaches that do not reach the same level of unanimity as exists for the underlying concepts.

Hannan (1989) was the first author to develop a model which aimed to explain the influence of legitimation and competition on mortality rates. This model is known as the density dependence model, and directly links density to mortality rates, analysing beforehand the relationship between density and legitimation, and between density and competition processes. The main supposition in this model maintains that legitimation and competition can be measured using the population density variable, that is, the number of organizations that form the population at any one moment.

Given that density is not a perfect measure of legitimation and competition, different studies have been developed in attempts to overcome this difficulty. We have grouped these into two separate approaches to the research according to the solutions they have offered to solve the problem in the initial model.

The first approach continues considering density as the principal measure of the phenomenon, but it is limited and specific to the parameters that register and isolate particular effects of the relationship. In contrast, the second approach abandons density as a basic measure, replacing it with new variables that are more in tune with the legitimation and competition relationships.

\section{Density Dependence Model}

The density dependence model comes directly from the population dynamics models applied to biotic populations. These models suggest that the intensity of competition depends on the number of organizations in a given population, and establishes that the growth of an isolated population follows an S-shaped growth path (Hannan and Freeman 1989, 99).

Density is used in biology owing to the difficulty in observing characteristics of the material environment affecting vital rates. The density dependence model developed by Hannan (1989) adopts the same approach, but incorporates sociological mechanisms. This model bases itself on the premise that density in the organizational world activates not only competitive processes but also institutional processes. In fact, this model considers that the levels of legitimation and competition are density functions.

New organizational forms lack legitimation. This hampers trading activity, since financial resources are not easily accessible, suppliers and customers must be attracted, recruiting and selection of human resources is difficult, etc. As the form proliferates, that is, as new organizations of this type are created, legitimation increases. Initially, when the number of organizations is low, the increase in legitimation of the organizational form is high when another organization is incorporated. However, when many organizations are present in the population, legitimation increases little, or not at all, as density rises. Consequently, legitimation ${ }^{1}$ increases with density at a decreasing rate, staying practically stationary at high-density levels (Hannan 1989).

With reference to competition, the impact of the incorporation of a new competitor is different according to the magnitude of the population density. When density is low, the incorporation of an organization slightly increases the frequency and strength of competitive interactions, but when density is high, the incorporation of an organization greatly increases competition. ${ }^{2}$ Consequently, the intensity of competition increases with density at an increasing rate (Hannan and Freeman 1989, 133-134).

This model relates organizational survival to the legitimation and competition processes. 
As legitimation rises, the problems in gaining resources necessary for organizations diminish. Therefore, their chances of survival increase. However, as competition intensifies, it becomes more difficult to keep up the flow of resources for the majority of organizations, which would imply that mortality is directly proportional to competition (Hannan and Carroll 1992).

Moreover, if we deduce that the influence of legitimation on death probability is superior to that of competition for low density levels, and that competition is superior to legitimation for high levels, the result of combining these two suppositions will be that death rates should decrease in an initial phase, and grow in a second phase, creating a Ushaped function.

This model has been tested on many occasions. The results appear in Table 1, which notes the authors who undertook the testing, the populations used, the study period, and the result of the tests carried out in each population, whether positive or negative, accompanied by the statistical significance.

Table 1 shows that few studies contradict, in any significant way, the conclusions of the density dependence model (eight of 71 studies), confirming its ability to explain mortality successfully.

The authors have offered different arguments to explain results that do not conform to the model. These are as follows.

- The lack of information about the initial years of the studied population: This fact would hamper the analysis of legitimation processes, since the model supposes that these processes operate on a high level in the formative period (Baum 1996; Hannan and Carroll 1992, 1995). If the starting point of the population is ignored, it is practically impossible to separate the legitimation effects from the competition effects as density increases (Hannan and Carroll 1995). This is the most accepted argument used by authors and allows explanation of the dissenting results of the studies carried out by Baum and Korn (1996), Boone et al. (2000), Ingram and Simons (2000), Silverman et al. (1997) and Staber (1992).

- The initial influence of the density on mortality rates: However, this can be motivated by unobserved heterogeneity, that is, the omission of a specific relevant variable of the organization that could have some bearing on organizational mortality (Petersen and Koput 1991). Density is a measure that probably reflects the effects of the omitted causal variables when models contain few control variables. This explains why some authors do not consider density to be a suitable measure for legitimation processes (Baum and Powell 1995; Petersen and Koput 1991; Zucker 1989). In research papers, it is possible to find alternatives not based on density in order to study such processes (see, for example, Lomi 2000; Rao 1994).

- The level of analysis used: The effects of density on legitimation and competition processes are different depending on the geographical environment selected (Carroll and Wade 1991; Hannan and Carroll 1992). The geographic scale of the legitimation process operates more broadly than the competition one (Hannan et al. 1995).

- The influence of population age: Hannan (1997) considers that the density dependence model is valid during the initial years of a population but loses this validity as the population ages. This is so because legitimation and competition processes become increasingly inert with population age.

\section{Models with New Density-based Measures}

As we have already pointed out, Hannan's (1989) model has gained considerable empirical support. Nevertheless, the variable used, population density, does not contemplate important factors that affect legitimation processes, and furthermore, competition processes. This has led to the development of models which introduce connotations within the density variable. 
Table 1. Empirical papers on density dependence model

\begin{tabular}{|c|c|c|c|}
\hline $\begin{array}{l}\text { Reference } \\
\text { Barnett and Carroll (1987) }\end{array}$ & $\begin{array}{l}\text { Analysed sample } \\
\text { lowa telephone companies }\end{array}$ & $\begin{array}{l}\text { Studied } \\
\text { interval }\end{array}$ & $\begin{array}{l}\text { Positive } \\
\text { support }\end{array}$ \\
\hline Hannan and Freeman (1988) & American labour unions & 18361985 & YES** \\
\hline Tucker et al. (1988) & Toronto voluntary social services & 19701982 & NO \\
\hline Delacroix et al. (1989) & Wineries in California & 19401985 & NO \\
\hline \multirow{4}{*}{ Carroll and Hannan (1989a) } & Argentinean newspapers & 18001900 & YES** \\
\hline & Irish newspapers & 18001975 & YES** \\
\hline & Little Rock newspapers & 18151975 & NO \\
\hline & Springfield newspapers & 18351975 & YES** \\
\hline \multirow[t]{5}{*}{ Carroll and Hannan (1989b) } & American labour unions & 18361985 & YES** \\
\hline & Argentinean newspapers & 18001900 & YES** \\
\hline & Irish newspapers & 18001970 & YES** \\
\hline & S. Francisco newspaper publishers & 18401975 & YES** \\
\hline & American breweries & 16331988 & YES** \\
\hline \multirow[t]{2}{*}{ Hannan and Freeman (1989) } & $\begin{array}{l}\text { American semiconductor } \\
\text { manufacturing firms }\end{array}$ & 19461984 & YES** \\
\hline & American labour unions & 18361985 & YES** \\
\hline Staber (1989) & Canadian worker cooperatives & 19401987 & NO \\
\hline Barnett and Amburgey (1990) & Pennsylvania telep hone companies & 18771933 & YES** \\
\hline Banaszak Holl et al. (1990) & Manhattan banks & 17911980 & YES** \\
\hline Carroll and Wade (1991) & American local brewing firms & 18001988 & NO \\
\hline \multirow[t]{2}{*}{ Swaminathan and Wiedenmayer (1991) } & $\begin{array}{l}\text { German state and national } \\
\text { brewing firms }\end{array}$ & 19001981 & YES** \\
\hline & German local brewing firms & 19001981 & NO \\
\hline Baum and Oliver (1992) & Day care centres in Toronto & 19711989 & YES** \\
\hline Baum and Mezias (1992) & Manhattan hotels & 18981990 & YES**a \\
\hline \multirow[t]{3}{*}{ Carroll and Swaminathan (1992) } & USA brewpubs & 19751990 & YES** \\
\hline & USA microbreweries & 19751990 & NO \\
\hline & USA mass production breweries & 19751990 & $\mathrm{NO}^{\mathrm{a}}$ \\
\hline \multirow[t]{7}{*}{ Hannan and Carroll (1992) } & American breweries & 16331988 & YES** \\
\hline & American labour unions & 18361985 & YES** \\
\hline & American life assurance companies & 17591900 & YES** \\
\hline & American banks & 17911980 & YES** \\
\hline & Argentinean newspapers & 18001900 & YES** \\
\hline & Irish newspapers & 18001975 & YES** \\
\hline & S. Francisco newspapers & 18451975 & YES** \\
\hline \multirow[t]{3}{*}{ Staber (1992) } & Canadian worker cooperatives & 19001987 & NO \\
\hline & Canadian marketing cooperatives & 19001987 & $\mathrm{NO} * *$ \\
\hline & Canada consumer cooperatives & 19001987 & YES** \\
\hline Wholey et al. (1992) & $\begin{array}{l}\text { American health maintenance } \\
\text { organizations }\end{array}$ & 19761991 & YES**a \\
\hline Aldrich et al. (1994) & American trade associations & 19011982 & YES** \\
\hline
\end{tabular}


Table 1 (Continued)

\begin{tabular}{|c|c|c|c|}
\hline Barnett and Hansen (1996) & Illinois banks & 19001993 & YES**a \\
\hline Baum and Korn (1996) & Californian air lines & 19791984 & $\mathrm{NO} * *$ \\
\hline Ingram and Inman (1996) & Niagara Falls hotels & 18851991 & YES** \\
\hline \multirow{3}{*}{ Hannan et al. (1998) } & Automobile manufacturers in France & 18851981 & YES** \\
\hline & Automobile manufacturers in Germany & 18851981 & $\mathrm{NO} * *$ \\
\hline & Automobile manufacturers in America & 18851981 & YES** \\
\hline Ruef and Scott (1998) & Hospitals & 19451990 & YES* \\
\hline Wade et al. (1998) & American breweries & 18451918 & YES** \\
\hline Dobrev et al. (2002) & USA automobile manufacturers & 18851981 & YES** \\
\hline
\end{tabular}

${ }^{a}$ These empirical papers consider density as control variable.

Statistical significance: $* p<0.10 ; * * p<0.05$.

\section{Cross-effects of Density Model}

The density dependence model is able to analyse competitive dynamics within a population, but not inter-population competition. When a population interacts with others, the success and survival of its members depend on the nature and strength of the ecological interactions with organizations of other populations (Baum 1996, 91).

Hannan's (1989) model only considers competition between the members of one population, but not that arising from organizations that belong to another population and whose fundamental niches intersect. The fundamental niche of a population is the whole of the social, political and economic conditions that uphold the operation of organizations integral with it (Hannan and Carroll 1992, 28). This problem is easily overcome if we take into account that mortality rates not only depend on the density of the given population, but also on the density of other populations (crossdensity). By widening the initial Lotka-Volterra framework, the competition between populations can be introduced. Therefore, a new model arises which takes into account both intra-population and inter-population competition. This is known as the cross-effects of density model (Hannan and Freeman 1989). It is clear that the more similarities that exist between the fundamental niches occupied by two populations, the greater will be the effect of population density on the competitive dynamics of each population. Nevertheless, the type and direction of this interdependence represents an interesting question, which can be analysed by this new model.

Ecologists distinguish three types of interdependence among populations (Hannan and Freeman 1989, 96-97): (1) competitive, (2) predator and (3) mutualistic (symbiotic). The term 'competition' is usually restricted to situations where the negative effect is mutual; that is, for cases such as those in which the presence of each population reduces the growth rate of another/other population(s) (Baum and Oliver 1991; Brittain 1994).

In other cases, competitive relationships can become predatory when the expansion of a population legitimates the other, but the growth of the second worsens the life chances 
of the first by eroding its resource base (Brittain 1994; Swaminathan and Wiedenmayer 1991). If balanced coexistence is not possible, the second population will proliferate and will invade the first population's niche, which will disappear in accordance with the competitive exclusion principle (Hannan and Freeman 1989). The relationships will be mutualistic when the expansion of one stimulates the expansion of another, and so reduces its mortality rate (Barnett 1990; Ingram and Baum 1997).

In other cases, only one of the cross-effects of density is present. The papers developed by Carroll and Swaminathan (1992) and Carroll and Wade (1991) show examples of mutualistic relationships in one single direction. In studies by Barnett (1990), Baum et al. (1995), Hannan and Freeman (1988) and Rao and Nielsen (1992), the relationship is competitive.

A final possibility is that interdependence may be non-monotonic. That is, growth in the density of a population could legitimate another one, until the density growth becomes so great that competitive interactions dominate. We can observe this in the results in the Silverman et al.'s study (1997), while in the papers by Hannan and Freeman (1989) and Staber (1992) opposite results were found.

\section{Delay Density Model}

The density dependence model holds that, to represent competition effects in mortality rates, it is only necessary to take into account current density. Nevertheless, competition could have delayed the effects on mortality rates (Carroll and Hannan 1989b). Supporting the idea put forward by Stinchcombe (1965) on the organizational impact of social conditions at the time of organizational founding, organizations may be exceptionally sensitive to competition when they are first established.

Working on this theory, Carroll and Hannan (1989b) develop a new model, which, as well as including density as in Hannan's (1989) model, also incorporates the density existing at the time of founding (or delay density). It is assumed that the number of organizations operating within a population at the time of foundation will mark the future evolution of the organization, producing a monotonic, positive and persistent effect on mortality rates, owing to resource scarcity or tight niche packing at that particular moment.

It is possible to come to the opposite conclusion regarding delay density effects. After the first few years of operation, organizations founded in periods of high density could present lower mean frailty than those founded in favourable circumstances. Consequently, the former organizations, having survived the initial stage of selection or the 'trial by fire', will present lower mortality rates than the latter organizations. That is, the persistent effect of delay density in mortality rates would be negative (Carroll and Hannan 1989b, 417).

Table 2 shows the studies which test the delay density hypothesis. Only the results of the studies made by Aldrich et al. (1994) and Barnett (1997) are consistent with the "trial by fire' conclusion.

Finally, Swaminathan (1996) goes into detail about the hypothesis of this model, which supposes that both resource scarcity and tight niche packing affect the initial mortality rate of organizations. He reasons, and empirically demonstrates, that only resource scarcity produces this initial effect, while tight niche packing generates a permanent risk in organizations founded in these circumstances. This difference arises because resource scarcity hampers the initial development of organizational capabilities, while tight niche packing permanently affects the competitive position of organizations within a population. Therefore, competitive positions are more difficult to change than organizational capabilities and reflect imprinting at the time of founding (Swaminathan 1996, 1.353).

\section{Direct Competition Model}

Another criticism made about the population density variable is its exclusive use of diffuse competition (Baum and Mezias 1992). That is to say, it assumes that all the organizations of a 
Table 2. Empirical papers on delay density model

\begin{tabular}{|c|c|c|c|}
\hline Reference & Analysed sample & $\begin{array}{l}\text { Studied } \\
\text { interval }\end{array}$ & $\begin{array}{l}\text { Positive } \\
\text { support }\end{array}$ \\
\hline \multirow[t]{5}{*}{ Carroll and Hannan (1989b) } & American labour unions & 18361985 & YES** \\
\hline & Argentinean newspapers & 18001900 & YES** \\
\hline & Irish newspapers & 18001970 & YES** \\
\hline & S. Francisco newspaper publishers & 18401975 & YES** \\
\hline & American breweries & 16331988 & YES** \\
\hline Carroll and Wade (1991) & American brewing industry & 18001988 & YES** \\
\hline \multirow[t]{2}{*}{ Carroll and Swaminathan (1992) } & USA microbreweries & 19751990 & YES \\
\hline & USA brewpubs & 19751990 & YES** \\
\hline \multirow[t]{7}{*}{ Hannan and Carroll (1992) } & American breweries & 18631985 & YES** \\
\hline & American labour unions & 18361985 & YES** \\
\hline & American life assurance companies & 17591900 & YES** \\
\hline & American banks & 17911980 & YES** \\
\hline & Argentinean newspapers & 18001900 & YES** \\
\hline & Irish newspapers & 18001975 & YES** \\
\hline & S. Francisco newspapers & 18451975 & YES** \\
\hline Wholey et al. (1992) & American health maintenance organizations & 19761991 & YES \\
\hline Aldrich et al. (1994) & American trade associations & 19011982 & $\mathrm{NO} * *$ \\
\hline Barron et al. (1994) & Credit unions in New York & 19141990 & YES** \\
\hline Ingram and Inman (1996) & Niagara Falls hotels & 18551991 & YES** \\
\hline Barnett and Hansen (1996) & Illinois banks & 19901993 & YES** \\
\hline \multirow[t]{2}{*}{ Swaminathan (1996) } & American breweries & 16331989 & YES** \\
\hline & Argentine newspapers & 18001900 & YES** \\
\hline \multirow[t]{2}{*}{ Barnet (1997) } & American breweries & 16331988 & YES** \\
\hline & Pennsylvania telephone companies & 18791934 & $\mathrm{NO} * *$ \\
\hline Ranger Moore (1997) & New York life insurance industry & 18131985 & YES** \\
\hline \multirow[t]{4}{*}{ Hannan et al. (1998) } & Automobile manufacturers in Britain & 18851981 & YES** \\
\hline & Automobile manufacturers in France & 18851981 & YES** \\
\hline & Automobile manufacturers in Germany & 18851981 & YES** \\
\hline & Automobile manufacturers in American & 18851981 & YES** \\
\hline Wade et al. (1998) & American breweries & 18451918 & YES** \\
\hline Boone et al. (2000) & Dutch auditing firms & 18991992 & YES** \\
\hline Dowell and Swaminathan (2000) & US bicycle industry & 18801918 & YES** \\
\hline Ingram and Simons (2000) & Israeli workers cooperatives & 19201992 & YES** \\
\hline Dobrev et al. (2002) & USA automobile manufacturers & 18851981 & YES** \\
\hline
\end{tabular}

Statistical significance: $* p<0.10 ; * * p<0.05$.

given population generate identical competitive pressure, regardless of their characteristics (size, geographic location, etc.).

Therefore, it is advisable to modify the density measure by including only direct competitors. That is, to introduce variables that cover density, but in terms of the number of enterprises presenting the same characteristics, for example, size, output prices or geographic location. In this way, a series of models arises, which by means of this adjusted density, represents more precisely the effects of competitive pressure at population level (Baum and Mezias 1992; Hannan and Freeman 1977).
From the theoretical point of view, the idea of direct competition arose with the pioneering article of Hannan and Freeman's (1977) population ecology. According to these authors, organizations compete more intensely with those that are of a similar size, assuming that organizations of different size use different structures and strategies and depend on different resource combinations.

Nevertheless, these authors developed these ideas on a strictly theoretical level, Hannan et al. (1990) being the first to introduce the innovation of measuring direct competition based on density in terms of organizational size. In 
this way, the model would not be defined by the global population density, but by the density of a specific number of enterprises of the same size (see, for example, Amburgey et al. 1994; Baum and Mezias 1992; Wholey et al. 1992).

However, size is not the only characteristic studied to analyse the behaviour of more direct competition. For example, it could be analysed by the effect of density within strategic groups (Barnett 1993), or within organizations that compete in different product/market situations at the same time (Baum and Korn 1996, 1999).

Another approach to the study of direct competition has been to divide density in terms of distance. Thus, to determine whether competition effects are stronger in a given population at local or at national level, for example, it is necessary to calculate the density for each geographical level. Several empirical studies point out that the incorporation of organizations in a population will produce more of a competitive impact on failure rates the more closely they are collocated (Baum and Singh 1994; Carroll and Wade 1991; Swaminathan and Wiedenmayer 1991). In any case, adequate analysis of competitive processes depends on the spatial structure of the population environment; that is, the more geographically segmented, the more localized the competition (Baum and Mezias 1992; Baum and Oliver 1996).

The results obtained by Baum and Mezias (1992) are consistent with these last two approaches and with the size-competition localized hypothesis. Specifically, they show how the intensity of competition is proportional to price equality, geographic location and size of the organizations.

One last approach to represent direct competition divides population density in terms of whether the organization occupies or does not occupy the same organizational niche. The niche concept is defined as the multidimensional spatial localization determined by resources in the environment (Hutchinson 1957), and refers to the population as a whole. The concept of organizational niche refers to the variation in productive capacities and environmental demands at organizational level (Baum and Singh 1994, 350). Every member of the population occupies an organizational niche and, therefore, a population embraces many organizational niches. From this, two new measures emerge: overlap density (organizations with the same organizational niche), and non-overlap density (organizations with different organizational niches). The empirical results indicate that overlap density affects competition intensity and, therefore, its growth increases mortality rates. However, non-overlap density influences the level of symbiosis, since organizations could benefit from the offer of products or services of complementary demand (Baum and Korn 1996; Baum and Singh 1994).

Every empirical paper that has addressed the direct competition models has positively tested them (see Amburgey et al. 1994; Barnett 1997; Barnett and Carroll 1987; Baum and Korn 1996; Baum and Mezias 1992; Baum and Singh 1994; Ingram and Inman 1996; Wholey et al. 1992). They demonstrate that organizational populations are divided into segments, and that the organizations in these segments respond heterogeneously to competitive processes that depend on density.

\section{Density Relational Model}

As previously mentioned, the effects of legitimation in failure rates have been calculated based on population density, which caused some authors to demand the use of more direct measures of the underlying institutional processes. Indeed, the density dependence model does not take into account the evolution of relationships maintained by the population with surrounding institutions. When these relationships are dense, the institutional actors can exert considerable influence over the conditions that regulate competition for scarce resources and legitimacy (Baum 1996, 89).

According to the institutional theory, the increase of embeddedness of a population in its institutional environment facilitates its 
growth and survival as time passes (Meyer and Scott 1983). With reference to the ecological theory, Baum and Oliver (1992) propose a hypothesis in which legitimation is explained in terms of the embeddedness of a population in its institutional environment. To this end, they define a new concept called 'relational density', which covers the number of relationships that organizations maintain with the key institutions in the environment.

The relational density model measures the effect generated in failure rates by links with key institutions, based on the supposition that these links grant organizations both legitimation and resources (Baum and Oliver 1992, 540). As a population grows, the organizations that constitute it become increasingly adapted to their institutional environment. Therefore, in the initial stage, increases in relational density should reduce mortality rates. In accordance with the institutional theory (Meyer and Rowan 1977; Meyer and Scott 1983), the long-term life expectancy of an organization should extend as adaptation to its institutional environment increases. However, once the said insertion has occurred, relational density does not create positive effects in mortality rates. This gives rise to a non-monotonic Ushaped relationship between relational density and failure rates. For those organizations that do not maintain direct relationships with their institutional environment, as would be expected, a non-monotonic inverted U-shaped relationship is produced.

Baum and Oliver (1992) test this relationship and conclude that organizations with direct links to key institutions have a greater life expectancy than those that do not have such links. Other studies, without referring directly to this model, confirm that connection with the institutional environment can increase the possibilities of survival and growth of a population, increasing legitimation and the members' capacity to mobilize resources (Hannan and Carroll 1992; Ingram and Inman 1996).

Conversely, Ruef and Scott (1998) analyse the impact of types of legitimation other than those that come from the institutional level. More specifically, they study the repercussion on organizational survival of technical and managerial legitimation. Ruef and Scott's (1998) results indicate that the importance of one or another type of legitimation can vary depending on the use of different institutional systems.

\section{Models Based on Variables other than Density}

Any density variable weights each organization in the same manner. That is, each organization exerts the same influence on its competitors within the niche, regardless of the particular characteristics of each organization belonging to the population, such as its market strength, size, etc. To resolve this problem, models have been developed that integrate other variables.

\section{Population Dynamic Model}

The model based on density takes into account the long-term effects of changes in this variable, but does not contemplate the effects of these changes in the short term. These transitory effects can be measured by the number of prior foundings and prior failings, and affect competitive dynamics in the population environment (Carroll and Hannan 1989a).

In this situation, the density dependence model would not be valid, given that it underestimates the capacity of organizations to avoid competition by migrating to neighbouring niches or enlarging their initial niche. Delacroix et al. (1989) have built an alternative model based on prior foundings and prior failings to explain mortality more fully. According to this model, commonly referred to in the literature as population dynamics, organizations that occupy highly congested niches are pressured into finding new survival chances, avoiding direct competition with established organizations, and reducing the pressure of dependent density competition. 
Introduction of the measure of prior foundings could be considered a 'proxy' variable, which indicates the existence of a new niche to which organizations can go to avoid being eliminated (Delacroix et al. 1989; Swaminathan and Delacroix 1991). Moreover, a high number of prior foundings indicates that the environment has, at its disposal, sufficient environmental resources to allow survival. For this reason, this measure should be negatively related to mortality rates.

Conversely, when an organization fails and ceases operating, the resources it releases can be used by other organizations. Each death could increase the viability of the survivors and reduce failure rates in the following stage (Delacroix and Carroll 1983). Consequently, both prior foundings and prior failures would reduce competition intensity and, therefore, would be negatively related to organizational mortality (Delacroix et al. 1989).

However, it is possible to form a contrary interpretation for the repercussions of failures that occurred during the previous year. These failures could be a symptom of a hostile environment which makes it difficult for the organizations of a population to obtain resources. Therefore, a large number of deaths the previous year could increase mortality rates. The studies made by Barnett and Hansen (1996), Ingram and Inman (1996) and RangerMoore (1997) support this hypothesis. Conversely, high rates of foundation could provoke market saturation, so incrementally increasing mortality rates (Delacroix and Carroll 1983). If the assumption that prior failures reduce mortality rates is accepted (Delacroix et al. 1989), it follows that, while prior foundings increase these rates, prior failures reduce them. This idea is empirically confirmed in the studies made by Aldrich et al. (1994) and Barnett (1997).

Table 3 shows the studies that incorporate prior foundings and failures in mortality models. It reveals that only three obtain results consistent with the hypothesis that both prior foundings and prior failures reduce competitive pressure at population level.

\section{Mass Dependence Model}

One of the most important limitations of the population density variable is the equal weighting of all populations regardless of their size. It ignores the fact that organizations can attain environmental carrying capacity, either by an increase in size or by an increase in numbers (Barnett and Carroll 1987, 411). Consequently, density would be a suitable variable when the environment did not offer opportunities or incentives for growth (Winter 1990).

Of those models based on density, only the direct competition models (Hannan and Freeman 1977; Hannan et al. 1990) consider the influence that organizational size exerts on competitive pressure at a population level. Large organizations can have a bearing on the competitive dynamics of a population and, therefore, on mortality rates (Barnett and Amburgey 1990).

In a homogeneous environment, when an organization grows in size, the amount of resources used increases, thereby causing a reduction in the chances of survival of those organizations that depend on them. Over time, the size of the individual large organization may displace, through competition, its population's size in numbers (Winter 1990). The immediate consequence is that large organizations increase their competitors' mortality rates (Barnett and Amburgey 1990, 80).

If the largest organizations were, at the same time, the strongest competitors, it would be necessary to incorporate a new variable that reflected the significance of these organizations. A possible solution would be to recalculate the density, weighting each organization by size (Barnett and Amburgey 1990; Hannan and Freeman 1989). This would introduce a new variable called population mass (Barnett and Amburgey 1990).

To resolve the limitations of the density variable, Barnett and Amburgey (1990) develop the mass dependence model, which directly links the aggregated size of the members of a population to failure rates. If large organizations are stronger competitors, 
Table 3. Empirical papers about models based on variables other than density

\section{Population dynamics model Reference}

\section{Hannan and Freeman (1988)}

Delacroix et al. (1989)

Carroll and Hannan (1989a)

\author{
Analysed sample
}

American labour unions

Wineries in California

S. Francisco Oakland S.José

newspapers

Argentinean newspapers

Irish newspapers

Little Rock newspapers

Springfield newspapers

Shreveport newspapers

Elmira newspapers

Lubbock newspapers

Lafayette newspapers

Californian wine industry

Californian wine industry

Day care centres in Toronto

American trade associations

Manhattan telecommunications firms

Illinois banks

Niagara Falls hotels

American breweries

New York life insurance industry
Foundations

positive support

It is not tested

YES**

NO

YES

NO

$\mathrm{NO}$ **

NO

$\mathrm{NO}$ **

$\mathrm{NO} * *$

YES

NO

YES**

YES**

NO

NO

YES**

not tested

not tested

$\mathrm{NO}$ **

not tested
Failings positive support

NO

YES**

$\mathrm{NO}$ **

$\mathrm{NO}$ **

$\mathrm{NO} * *$

NO

YES

NO

YES

NO

NO

YES

YES**

YES**

YES**

YES**

$\mathrm{NO} * *$

$\mathrm{NO} * *$

YES**

$\mathrm{NO}$ **

Ranger Moore (1997)

Mass dependence model

Reference

Analysed sample

Studied interval

Incidence of themass on mortality

rates

Barnett and Carroll (1987)

Barnett and Amburgey (1990)

Baum and Mezias (1992)

Hannan and Carroll (1992)

lowa telephone companies

Pennsylvania telephone companies

Manhattan hotels

American breweries

American labour unions

American life assurance companies

USA mass production breweries

Pennsylvania telephone companies

Manhattan Hotels

Dutch auditing firms

$\begin{array}{ll}1900 & 1917 \\ 1877 & 1933 \\ 1898 & 1990 \\ 1863 & 1985 \\ 1890 & 1985 \\ 1759 & 1900 \\ 1975 & 1990 \\ 1879 & 1934 \\ 1898 & 1980 \\ 1899 & 1992\end{array}$

Positive Negative**

Positive**

Positive**

Negative

Positive

Positive

Negative **

Negative**

Negative

Boone et al. (2000)

Analysed sample

Studied interval Positive support

Reference

Newspapers in seven USA

metropolitan areas

USA microbreweries

USA brewpubs

USA mass production breweries

USA microbreweries

Medical diagnostic imaging

manufacturers

Airlines in California

Dutch auditing firms

Bulgarian specialist newspapers

USA automobile manufacturers

$\begin{array}{lll}1800 & 1975 & \text { YES** } \\ 1975 & 1990 & \text { YES** } \\ 1975 & 1990 & \text { NO } \\ 1975 & 1990 & \text { YES } \\ 1975 & 1988 & \text { YES** } \\ 1950 & 1988 & \text { YES** } \\ 1979 & 1984 & \text { YES** } \\ 1899 & 1992 & \text { YES** } \\ 1987 & 1990 & \text { YES* } \\ 1885 & 1981 & \text { YES** }\end{array}$

Statistical significance: $* p<0.10 ; * * p<0.05$. 
increases in population mass should have a competitive effect, increasing the failure rates of smaller organizations.

From an empirical point of view (Table 3), the results obtained in studies that incorporate mass in mortality models are not conclusive. Thus, Baum and Mezias (1992) and Hannan and Carroll (1992) find a competitive effect produced by the population mass. Nevertheless, Barnett (1997), Barnett and Amburgey (1990) and Ingram and Baum (1997) find a mutualistic effect of mass on the risk of failure. According to Barnett (1997), large firms are weak competitors but strong survivors. For this reason, he argues that population mass effects should actually reduce the mortality of other firms.

\section{Resource-partitioning Model}

The mass variable omits an important component of competitive pressure, namely, the difference in size among organizations of a population. To overcome this obstacle, the level of concentration should be included as a relevant variable that has an influence on organizational death.

Several studies include concentration as a control variable in order to predict organizational mortality. The great majority does not find statistical significance in its repercussions (Barnett 1997; Barnett and Carroll 1987; Wholey et al. 1992). However, Boone et al. (2000) find a competitive impact on the concentration of the population.

In organizational ecology, concentration is also used to examine inter-organizational relationships between generalist and specialist organizations (Carroll 1985). In ecological terms, the specialization level in a population is related to the niche width ${ }^{3}$ (Freeman and Hannan 1983; Hannan and Freeman 1977).

Based on niche width, Carroll (1985) developed the resource-partitioning model which assesses survival chances of specialist organizations using the population concentration level as a predictive variable. According to this model, when economies of scale are present in an industry, only a few generalist organizations can survive by moving towards the centre of the market. This reduction in the number of generalists and their move towards the centre, gives rise to the creation of resource pockets on the periphery, where specialist organizations can appear and prosper. In this context, the market will have been divided into specialist and generalist resources, as the name of the model suggests (Carroll and Hannan 1995).

From the above, it is possible to predict that when the market is not concentrated, specialist and generalist organizations compete directly for the same resources, negatively affecting the specialists' survival chances. However, when the market is highly concentrated, survival chances for these organizations are increased.

We can relate the resource-partitioning hypothesis with the size-localized competition hypothesis, according to which competition between pairs of organizations within a population will be a decreasing function of the distance separating them on the size gradient (Hannan and Freeman 1977, 945). Similarly, Meyer (1990) argues that the resourcepartitioning model provides a possible base for the specification of Hannan and Freeman (1977) on competition based on size: large organizations capture the advantages of generalism, small organizations capture the advantages of specialism, and middle-sized organizations capture the liabilities of both. The connection between the models mentioned has been observed in the studies made by Boone et al. (2000), Carroll and Swaminathan (1992), Dobrev (2000), Dobrev et al. (2002) and Lomi (1995).

Examining the literature that has empirically tested this model to predict mortality (Table 3), four interesting questions arise: (1) none of the studies has been made at a geographical scale above the national level; (2) the existence of scale economies should not be a restrictive condition for the model, as support for it should be found in lowscale economy populations (Mascarenhas 1996, 
$31)$; (3) the great majority of the studies made are based on populations which operate in consumer markets, and it would be convenient to test the model in industrial markets (Boone et al. 2000); and (4) this model is formulated in a context in which concentration increases, but which does not investigate the consequences of reduction in concentration (Dobrev 2000, 383). Dobrev (2000), looking closely at this last topic, finds that resource-partitioning processes are reversible and, therefore, reduction in concentration increases the risk of disbanding of specialist organizations.

Conversely, repercussion caused by an increase in concentration can be interpreted in another way. According to the oligopoly theory, concentration makes coordination between organizations possible, bringing about a reduction in the output rates in concentrated markets (Baum and Korn 1996). Despite this, the only study that tests this hypothesis in the organizational ecology environment does not manage to validate it, but does find support for the resource-partitioning model (see Baum and Korn 1996).

In the last few years, substantial theoretical contributions have been made to the resourcepartitioning model as conceived by Carroll (1985). Péli and Nooteboom (1999) widen the initial framework of the resource-partitioning model into a two-dimensional space. The results obtained by these authors demonstrate that the proportion of specialist space increases rapidly as the number of dimensions in the space increases. This generates a complementary set of empirical predictions associating expansion in resource space with enhanced specialist viability. More specifically, the initial hypothesis would be that, as the number of dimensions in resource space increases, the mortality rates of specialist organizations declines (Carroll and Hannan 2000, 268).

In addition, we should point out that the resource-partitioning model could be used to estimate legitimation of the organizational forms present within a given industry. To this end, the initial mechanism underlying Carroll's (1985) model on the localization of an organization in the resource space should remain in the background, and another mechanism of a sociological nature should be used as the organizational identity. In American beer brewing, the identity problems confront the mass-production and contract brewers. Mass-production firms are too large, bureaucratic, and commercial; contract brewers do not even make their own beer (Carroll and Swaminathan 2000). By considering normative and counter-normative specialist organizational forms sanctioned by a tight-knit, knowledgeable community, the density effects could be different from those of the Hannan (1989) model (Carroll and Hannan 2000, 273). Carroll and Swaminathan (2000) argue that as the density of specialist organizational forms with positive normative sanctions rises, the legitimation of all specialist forms is enhanced, while the opposite is the case for counternormative forms; that is, as density rises, the legitimation of all specialist forms should slow. Moreover, among the positively sanctioned forms, it is to be expected that the strongest effects would come from those with greatest visibility. To summarize, taking into account the supposition of resource partitioning in identity, the legitimizing density effects on specialists depend on the normative status and the social visibility of the specialist form.

Finally, there are models that improve the predictions of the resource-partitioning model. These analyse the processes of positioning and crowding among firms in the niche space, relating them to the level of concentration among all firms in the market. Dobrev et al. (2001) found that broad niche width lowers rates of death but that niche overlap heightens the risk of mortality to an extent that more than offsets the broad niche advantage. Their paper also shows that mortality chances rise when a producer firm substantially changes its niche width or its position. Dobrev et al. $(2002,262)$ found that both niche width and position in the favourable market centre lower organizational mortality rates. However, they found that the effects of niche width and position depend on the overall consolidation of the 
industry, reversing themselves in cases of high concentration.

\section{Conclusions}

From the ecological perspective, it is essential to understand the causes of environmental selection. There is complete agreement among ecology researchers that the effects of legitimation and competition are partly responsible for organizational selection processes. The key question is to find an adequate variable or variables that allow these concepts to be brought together. Initially, it was thought that both processes could be measured from the population density, giving rise to the building of the density dependence model (Hannan 1989). This model has proved to be extremely robust and general, given that it has been validated in several populations and under different environmental contexts. Despite this, density is a measure that can clearly be improved. This fact has been recognized throughout the stream of research presented in this paper. Efforts made to overcome inefficiencies have given rise to the models expounded in this study. We have grouped these together in two fundamental lines of research based on the different types of variables used by the authors.

Through the development of this study, we believe we have contributed to clarifying the nature of this stream of investigation, compiling the main research done, and informing on its current situation. However, in view of the research done, we can also conclude that it is a line of investigation that could continue evolving if we take into consideration its current limitations.

First, we point out that each of the models continues to use only one variable (density and its variations, mass or concentration) to measure the two initial concepts used in the theory (legitimation and competition). A special mention is required for the model of Baum and Oliver (1992), which attempts to measure the effect of legitimation, although it does not use a specific variable, but isolates this effect by specifying the density. In the last few years, other studies have been made to try bringing together the concept of legitimation through measures other than density (Hybels et al. 1994; Lomi 2000; Rao 1994). The majority of these confine themselves to the organizational founding environment, leaving, as a challenge to researchers, the proposal and validation of new measures in the field of mortality. Similarly, the arguments about resource partitioning based on organizational identity, described by Carroll and Swaminathan (2000), must be theoretically and empirically developed.

Little attention has been given to the fact that some organizational forms reach a takenfor-granted status more easily than do others (Dobrev 2001, 419). It would be interesting to provide new insight about the multifaceted nature of legitimation to ensure contextual accuracy and proper definition of organizational forms in different environments.

Although, in this stream of research, every effort has been concentrated on the development of new variables which move closer to the competition concept, the same problems have been encountered as those found in the cross-effects of density models. In these models, competition is not contemplated among organizations belonging to different populations, and the competitive conditions prevailing at the moment of foundation are ignored. For this reason, it would be convenient to develop models that include mass, or the concentration of other populations, or that include mass or delay concentration, just to mention a few examples.

Nevertheless, the cross-effects of density put forward a formal outline to analyse competition within, and between, strategic groups that make up an industry. An ecological approach to strategic groups helps strategic management, providing a model of the effects of organizational strategies and of membership of such groups (Baum 1996, 92).

Although the studies mentioned in the population dynamic model put forward empirical evidence of the existence and type of 
competition present among populations, very few attempts have been made to predict the specific type of interaction that exists among them. It is advisable that the advance in this direction puts forward arguments that justify the existence of competition or symbiosis among populations where fundamental niches intersect. It should be noted that the LotkaVolterra framework does not lead to examination of evolutionary processes that go further than a simple variation in density, although it is useful that the cross-effects of the density model are based on this framework. For instance, technological or institutional change can be more favourable for some organizational forms than for others (Amburgey and Rao 1996, 1.282).

Another limitation in this stream of research is its tendency to generalize. Questions that are more specific must be researched. In this sense, Hannan's (1997) contribution which questions the validity of the density dependence model must be applauded, as it considers that population age may modify the effects of density. In this respect, a challenge to researchers would be to verify whether population age could also modify the effects on the legitimation and competition predicted by the models that use variables other than density.

The practical matter of the difficulty of measuring constructs with the typical ecological data set must be pointed out. For many populations, it is difficult to measure time-varying organizational size, which is a key variable for understanding the effects of mass and for understanding size-localized competition. Restricting ecological studies to those populations for which such measures are available may introduce potentially dangerous biases.

We also observe that in all the models mentioned there are exceptions that empirically contradict the norm developed theoretically, which makes us think that there are latent effects that have not been explained by the theory. The understanding of these effects is essential to enable us to specify the conditions under which predictions are sustained and to increase precision. In widening this field of research, it would be necessary to assess the effects of organizational legitimation coming from density simultaneously with reputation at organizational level. Research into this and other related topics is necessary to clarify boundary conditions of density dependence (Amburgey and Rao 1996, 1.272).

Likewise, it would be advisable to develop a line of research which analyses relationships between competitive conditions at organizational level and dynamics of rivalry between organizations. It would be interesting to examine how market domination affects failure rates, or to see whether multi-market contact between organizations, or pairs of organizations, facilitates collaboration or cooperative behaviour. Similarly, the growth of network organizational forms may contribute new ideas about the level at which complementary assets, coordination problems and legitimacy shortages reveal the rise and fall of organizational forms (Amburgey and Rao 1996, 1.281).

Another possible challenge would be to use the models mentioned in this study to help social movement theorists explain the relationships which exist between moderate and radical social-movement organizations. For this purpose, the resource-partitioning model can be used to model diffuse competition among organizations and predict the rates at which they attract new members. The density dependence model can be used to throw light on both the joint evolution of both organizations and how organizational dynamics underline their rise and fall (Amburgey and Rao 1996, 1.281).

In the field of labour, future research could link this stream of investigation with the analysis of professions. The density dependence model could be used to explain professional dominance over a certain market (Amburgey and Rao 1996, 1.282); for instance, to explain how the growth of new information and communication technologies has favoured the rise of new professions (network administrators, website designers, analysts, programmers, etc.) and the fall of others. This model can 
also be used to explain why certain industries, or periods, experience higher levels of involuntary job mobility. From a public policy viewpoint, the demographic processes associated with these involuntary moves would seem to deserve the most attention because they potentially generate the greatest social costs (Carroll and Hannan 2000, 433).

Another inconclusive debate that is not studied in this paper is the one initiated by Carroll (1997) and Carroll and Hannan (2000, Ch. 11 and 12), regarding the suitability of some models that should represent the phenomenon, observed empirically, of the decline and subsequent rise in the number of organizations in a population when they are in a mature phase.

Lastly, we must also mention that of all the streams of research carried out within organizational ecology, the stream described in this study is probably the one that has lasted longest without receiving outside influence which has considerably modified the content of the models. Nevertheless, as has occurred in other theories, a new area of research has opened up as a result of overlapping with other lines of research such as the institutional theory (Baum and Powell 1995; Boone et al. 2000; Zucker 1989), the resource dependence perspective (Pfeffer and Salancik 1978) or even with strategic management, in a wider sense, when organizational heterogeneity models have to be explained (Amburgey and Rao 1996; Carroll and Hannan 2000; Cockburn et al. 2000). These challenges, together with the interest shown by researchers in this line of investigation in the last decade, allow us, as already pointed out by Amburgey and Rao (1996), Carroll (1997), Carroll and Hannan (2000) and van Witteloostuijn (2000), to be optimistic about the future that awaits this stream of research.

\section{Acknowledgements}

We are deeply grateful to Isabel Gutiérrez for her interesting comments. The investigation was funded by SEC (2001-0657) and FEGAFEOGA (CA099-019).

\section{Notes}

1 This type of legitimation is known as cognitive legitimacy (Baum 1996, 88; Carroll and Hannan 2000, 223). There is another type of legitimation known as social-political legitimacy (Baum 1996, 88) which is understood to be the conformity to social and institutional expectations (DiMaggio and Powell 1983). Although institutionalists view these two facets of legitimation as complementary, this stream of investigation emphasizes cognitive legitimacy.

2 This type of competition is called diffuse competition, since it does not mean that organizations have to take into account the action of others, or even be aware of their existence. There is another type of competition known as direct competition, which is established between pairs of organizations, each of which is aware of the rivalry which exists between them (Hannan and Carroll 1992).

3 The niche width refers to the range of environmental dimensions within which a population can exist. In accordance with this niche width, we can distinguish generalist organizations that depend on a wide range of environmental resources for survival, and specialist organizations that survive in specific environmental conditions. If resources are homogeneously distributed among organizations, a direct relationship is to be expected between niche width and size. That is to say, specialist organizations are normally smaller than generalist organizations.

\section{References}

Aldrich, H.E., Zimmer, C.R., Staber, U.H. and Beggs, J.J. (1994). Minimalism, mutualism and maturity: the evolution of the American Trade Association population in the 20th century. In Baum, J.A.C. and Singh, J.V. (eds), Evolutionary Dynamics of Organization. New York: Oxford University Press.

Amburgey, T.L. and Rao, H. (1996). Organizational ecology: past, present, and future directions. Academy of Management Journal, 39, 1.265-1.286.

Amburgey, T.L., Dacin, T. and Kelly, D. (1994). Disruptive selection and population segmentation: interpopulation competition as a selection process. In Baum, J.A.C. and Singh, J.V. (eds), Evolutionary Dynamics of Organization. New York: Oxford University Press.

Banaszak-Holl, J., Ranger-Moore, J. and Hannan, M.T. (1990). Density dependence in the mortality processes of financial institutions: American Life Insurance 
Companies and Manhattan Banks. Technical Report 90-1. Department of Sociology, Cornell University.

Barnett, W.P. (1990). The organizational ecology of a technological system. Administrative Science Quarterly, 35, 31-60.

Barnett, W.P. (1993). Strategic deterrence among multipoint competitors. Industrial and Corporate Change, 2, 249-278.

Barnett, W.P. (1997). The dynamics of competitive intensity. Administrative Science Quarterly, 42, $128-160$.

Barnett, W.P. and Amburgey, T.L. (1990). Do larger organizations generate stronger competition? In Singh, J.V. (ed.), Organizational Evolution: New Directions. Newbury Park: Sage.

Barnett, W.P. and Carroll, G.R. (1987). Competition and mutualism among early telephone companies. Administrative Science Quarterly, 32, 400-421.

Barnett, W.P. and Hansen, M.T. (1996). The Red Queen in organizational evolution. Strategic Management Journal, 17, 139-157.

Barron, D.N., West, E. and Hannan, M.T. (1994). A time to grow and a time to die: growth and mortality of credit unions in New York, 1914-1990. American Journal of Sociology, 100, 381-421.

Baum, J.A.C. (1996). Organizational ecology. In Clegg, S.R., Hardy, C. and Nord, W.R. (eds), Handbook of Organization Studies. London: Sage.

Baum, J.A.C. and Korn, H.J. (1996). Competitive dynamics of interfirm rivalry. Academy of Management Journal, 39, 255-291.

Baum, J.A.C. and Korn, H.J. (1999). Dynamics of dyadic competitive interaction. Strategic Management Journal, 20, 251-278.

Baum, J.A.C. and Mezias, S. (1992). Localized competition and organizational failure in the Manhattan Hotel Industry, 1898-1990. Administrative Science Quarterly, 37, 580-604.

Baum, J.A.C. and Oliver, C. (1991). Institutional linkages and organizational mortality. Administrative Science Quarterly, 36, 187-218.

Baum, J.A.C. and Oliver, C. (1992). Institutional embeddedness and the dynamics of organizational populations. American Sociological Review, 57, 540559.

Baum, J.A.C. and Oliver, C. (1996). Toward an institutional ecology of organizational founding. Academy of Management Journal, 39, 1.378-1.427.

Baum, J.A.C. and Powell, W. (1995). Cultivating an institutional ecology of organizations. American Sociological Review, 60, 529-538.
Baum, J.A.C. and Singh, J.V. (1994). Organizational niches and the dynamics of organizational mortality. American Journal of Sociology, 100, 346-380.

Baum, J.A.C., Korn, H.J. and Kotha, S. (1995). Dominant designs and population dynamics in Telecommunications Services: founding and failure of facsimile transmission service organizations, 19651992. Social Science Research, 24, 97-135.

Boone, C., Bröcheler, V. and Carroll, G.R. (2000) Custom service: application and tests of resourcepartitioning theory among Dutch auditing firms from 1896 to 1992. Organization Studies, 21, 355381.

Brittain, J.W. (1994). Density-independent selection and community evolution. In Baum, J.A.C. and Singh, J.V. (eds), Evolutionary Dynamics of Organization. New York: Oxford University Press.

Carroll, G.R. (1985). Concentration and specialization: dynamics of niche width in populations of organizations. American Journal of Sociology, 90, $1.263-1.283$.

Carroll, G.R. (1997). Long-term evolutionary change in organizational populations: theory, models and empirical findings in industrial demography. Indus trial and Corporate Change, 6, 119-143.

Carroll, G.R. and Hannan, M.T. (1989a). Density dependence in the evolution of populations of newspaper organizations. American Sociological Review, 54, 524-541.

Carroll, G.R. and Hannan, M.T. (1989b). Density delay in the evolution of organizational populations: a model and five empirical tests. Adminis trative Science Quarterly, 34, 411-430.

Carroll, G.R. and Hannan, M.T. (1995). Resource partitioning. In Carroll, G.R. and Hannan, M.T. (eds), Organizations in Industry. New York: Oxford University Press.

Carroll, G.R. and Hannan, M.T. (2000). The Demography of Corporations and Industries. Princeton, NJ: Princeton University Press.

Carroll, G.R. and Swaminathan, A. (1992). The organizational ecology of strategic groups in the American brewing industry from 1975 to 1990 Industrial and Corporate Change, 1, 65-97.

Carroll, G.R. and Swaminathan, A. (2000). Why the microbrewery movement? Organizational dynamics of resource partitioning in the U.S. brewing industry. American Journal of Sociology, 106, 715-762.

Carroll, G.R. and Wade, J. (1991). Density dependence in the organizational evolution of the American brewing industry across different levels. Social Science Research, 20, 271-302. 
Cockburn, I.M., Henderson, R.M. and Stern, S. (2000). Untangling the origins of competitive advantage. Strategic Management Journal, 21, 1.123-1.145.

Delacroix, J. and Carroll, G.R. (1983). Organizational foundings: an ecological study of the newspaper industries of Argentina and Ireland. Administrative Science Quarterly, 28, 274-291.

Delacroix, J. and Swaminathan, A. (1991). Cosmetic, speculative, and adaptive organizational change in the wine industry: a longitudinal study. Administrative Science Quarterly, 36, 631-662.

Delacroix, J., Swaminathan, A. and Solt, M.E. (1989). Density dependence versus population dynamics: an ecological study of failings in the California wine industry. American Sociological Review, 54, 245-262.

DiMaggio, P.J. and Powell, W.W. (1983). The iron cage revisited: institutional isomorphism and collective rationality in organizational fields. American Sociological Review, 48, 147-160.

Dobrev, S.D. (2000). Decreasing concentration and reversibility of the resource partitioning process: supply shortages and deregulation in the Bulgarian newspaper industry, 1987-1992. Organization Studies, 21, 383-404.

Dobrev, S.D. (2001). Revisiting organizational legitimation: cognitive diffusion and sociopolitical factors in the evolution of Bulgarian newspaper enterprises, 1846-1992. Organization Studies, 22, 419-444.

Dobrev, S.D., Kim, T.Y. and Hannan, G.R. (2001). Dynamics of the niche width and resource partitioning. American Journal of Sociology, 106, 1299-1337.

Dobrev, S.D., Kim, T.Y. and Carroll, G.R. (2002). The evolution of organizational niches: U.S. Automobile Manufacturers, 1885-1981. Administrative Science Quarterly, 47, 233-264.

Dowell, G. and Swaminathan, A. (2000). Racing and back-pedaling into the future: new product introduction and organizational mortality in the US bicycle industry, 1880-1918. Organization Studies, 21, 405-431.

Freeman, J. (1990). Ecological analysis of semiconductor firm mortality. In Singh, J.V. (ed.), Organizational Evolution: New Directions. Newbury Park: Sage.

Freeman, J. and Hannan, M.T. (1983). Niche width and the dynamics of organizational populations. American Journal of Sociology, 88, 1.116-1.145.

Hannan, M.T. (1989). Competitive and institutional processes in organizational ecology. In Berger, J., Zelditch, M. and Andersen, B. (eds), Sociological Theories in Progress: New Formulations. Newbury Park: Sage.
Hannan, M.T. (1997). Inertia, density and the structure of organizational populations: entries in European automobile industries, 1886-1989. Organization Studies, 18, 193-228.

Hannan, M.T. and Carroll, G.R. (1992). Dynamics of Organizational Populations: Density, Legitimation and Competition. New York: Oxford University Press.

Hannan, M.T. and Carroll, G.R. (1995). Theory building and cheap talks about legitimation. American Sociological Review, 60, 539-544.

Hannan, M.T. and Freeman, J. (1977). The population ecology of organizations. American Journal of Sociology, 82, 929-964.

Hannan, M.T and Freeman, J. (1988). The ecology of organizational mortality: American Labor Unions, 1836-1985. American Journal of Sociology, 94, 25-52.

Hannan, M.T. and Freeman, J. (1989). Organizational Ecology. Cambridge, MA: Harvard University Press.

Hannan, M.T., Carroll, G.R., Dundon, E.A. and Torres, J.C. (1995). Organizational evolution in multinational context: entries of automobile manufacturers in Belgium, Britain, France, Germany and Italy. American Sociological Review, 60, 509-528.

Hannan, M.T., Carroll, G.R., Dobrev, S.D. and Han, J. (1998). Organizational mortality in European and American automobile industries. Part I: revisiting the effects of age and size. European Sociological Review, 14, 279-302.

Hannan, M.T., Ranger-Moore, J. and Banaszak-Holl, J. (1990). Competition and the evolution of organizational size distributions. In Singh, J.V. (ed.), Organizational Evolution: New Directions. Newbury Park: Sage.

Hutchinson, G.E. (1957). Concluding remarks. Cold Spring Harbor Symposium on Qualitative Biology, 22, 415-427.

Hybels, R., Ryan, A. and Barley, S. (1994). Alliances, legitimation, and founding rates in the U.S. biotechnology field, 1971-1989. Paper presented at the Academy of Management Meeting, Dallas, TX.

Ingram, P. and Baum, J.A.C. (1997). Chain affiliation and the failure of Manhattan Hotels, 1898-1980. Administrative Science Quarterly, 42, 68-102.

Ingram, P. and Inman, C. (1996). Institutions, intergroup competition, and the evolution of hotel populations around Niagara Falls. Administrative Science Quarterly, 41, 629-658.

Ingram, P. and Simons, T. (2000). State formation, ideological competition, and the ecology of Israeli workers' cooperatives, 1920-1992. Administrative Science Quarterly, 45, 25-53. 
Lomi, A. (1995). The population and community ecology or organizational founding: Italian cooperative banks, 1936-1989. European Sociological Review, 11, 75-98.

Lomi, A. (2000). Density dependence and spatial duality in organizational founding rates: Danish commercial banks, 1846-1989. Organization Studies, 21, 433-461.

Mascarenhas, B. (1996). The founding of specialist firms in a global fragmenting industry. Journal of International Business Studies, 27, 27-42.

Meyer, M.W. (1990). Notes of a skeptic: from organizational ecology to organizational evolution. In Singh, J.V. (ed.), Organizational Evolution: New Directions. Newbury Park: Sage.

Meyer, J. and Rowan, B. (1977). Institutionalized organizations: formal structure as myth and ceremony. American Journal of Sociology, 83, 340-363.

Meyer, J.W. and Scott, W.R. (1983). Organizational Environments: Ritual and Rationality. Beverly Hills: Sage.

Mitchell, W. (1995). Medical diagnostic imaging manufacturers. In Carroll, G.R. and Hannan, M.T. (eds), Organizations in Industry. New York: Oxford University Press.

Péli, G. and Nooteboom, B. (1999). Market partitioning and the geometry of resource space. American Journal of Sociology, 104, 1.132-1.153.

Petersen, T. and Koput, K.W. (1991). Density dependence in organizational mortality: legitimacy or unobserved heterogeneity. American Sociological Review, 56, 399-409.

Pfeffer, J. and Salancik, G.R. (1978). The External Control of Organizations: A Resource Dependence Perspective. New York: Harper \& Row.

Ranger-Moore, J. (1997). Bigger may be better, but is older wiser? Organizational age and size in the New York life insurance industry. American Sociological Review, 58, 903-920.

Rao, H. (1994). The social construction of reputation: certification contests, legitimation and the survival of organizations in the American automobile industry, 1895-1912. Strategic Management Journal, 15, 29-44.

Rao, H. and Nielsen, E. (1992). An ecology of agency arrangements: mortality of savings and loan associations, 1960-1987. Administrative Science Quarterly, 37, 448-470.

Ruef, M. and Scott, W.R. (1998). A multidimensional model of organizational legitimacy: hospital survival in changing institutional environments. Administrative Science Quarterly, 43, 877-904.
Silverman, B.S., Nickerson, J.A. and Freeman, J. (1997). Profitability, transactional alignment and organizational mortality in the U.S. trucking industry. Strategic Management Journal, 18, 31-52.

Singh, J.V. and Lumsden, C.J. (1990). Theory and research in organizational ecology. Annual Review of Sociology, 16, 161-195.

Staber, U.H. (1989). Age dependence and historical effects on the failure rates of worker cooperatives. Economic and Industrial Democracy, 10, 59-80.

Staber, U.H. (1992). Organizational interdependence and organizational mortality in the cooperative sector: a community ecology perspective. Human Relations, 45, 1.191-1.212.

Stinchcombe, A.L. (1965). Social structure and organizations. In March, J.G. (ed.), Handbook of Organizations. Chicago: Rand-McNally.

Swaminathan, A. (1996). Environmental conditions at founding and organizational mortality: a trial-byfire model. Academy of Management Journal, 39, 1.350-1.377.

Swaminathan, A. and Delacroix, J. (1991). Differentiation within an organizational population: additional evidence from the wine industry. Academy of Management Journal, 34, 679-692.

Swaminathan, A. and Wiedenmayer, G. (1991). Does the pattern of density-dependence in organizational mortality rates vary across levels of analysis? Evidence from the German brewing industry. Social Science Research, 20, 45-73.

Tucker, D.J., Singh, J.V., Meinhard, A.G. and House, R.J. (1988). Ecological and institutional sources of change in organizational populations. In Carroll, G.R. (ed.), Ecological Models of Organizations. Cambridge: Ballinger.

Van Witteloostuijn, A. (2000). Organizational ecology has a bright future. Organization Studies, 21, vi-xiv.

Wade, J.B., Swaminathan, A. and Scott, M. (1998). Normative and resource flow consequences of local regulations in the American brewing industry, 18451918. Administrative Science Quarterly, 43, 905-935.

Wholey, D.R., Christianson, J.B. and Sánchez, S.M. (1992). Organization size and failure among health maintenance organizations. American Sociological Review, 57, 829-842.

Winter, S.G. (1990). Survival, selection, and inheritance in evolutionary theories of organization. In Singh, J.V. (ed.), Organizational Evolution: New Directions. Newbury Park: Sage.

Zucker, L.G. (1989). Combining institutional theory and population ecology: no legitimacy, no history. American Sociological Review, 54, 542-545. 
